\title{
Impacts of the New - generation Free Trade Agreements on Vietnam's Finance and Banking Sector
}

\author{
Pham Thanh Nga \\ Member, Vietnam Society of International Law, Hanoi, Vietnam \\ Email address: \\ pham.nga.hlu@gmail.com
}

\section{To cite this article:}

Pham Thanh Nga. Impacts of the New - generation Free Trade Agreements on Vietnam's Finance and Banking Sector. International Journal of Management and Fuzzy Systems. Vol. 6, No. 4, 2020, pp. 64-71. doi: 10.11648/j.ijmfs.20200604.12

Received: November 10, 2020; Accepted: November 25, 2020; Published: December 31, 2020

\begin{abstract}
In recent years, many countries around the World have intensified the signing of multilateral and bilateral Free Trade Agreements (FTAs) to create free trade areas after agreements within the WTO standstill. Not outside this trend, Vietnam has negotiated and signed many FTAs with many countries around the World. Notable are the new-generation FTAs in recent years with European countries (European Union - Vietnam Free Trade Agreement - EVFTA) or Pacific area (Comprehensive and Progressive Agreement for Trans-Pacific Partnership - CPTPP). These new - generation FTA have significant impacts on all socio-economic activities of Vietnam, especially in the field of finance and banking. They will not only open the market for investors from EU or other countries but also give the Vietnamese clients have chance to use more kinds of products and services in banking and financing field. In the framework of this article, the author will analyze more detail the impacts of the new - generation FTAs on financial and banking activities of Vietnam. Base on this analysis, author will give the conclusions and propose some solutions to implement better the new generation FTAs' advantages for Vietnam Finance - Banking sector. To finish this paper, the author used many methodologies research such as analyzing, comparison, refer the legal documents, survey questionnaire also used for the study. Moreover, various modelling approaches and levels of aggregation have been used for analysing industrial location such as ordinary least squares.
\end{abstract}

Keywords: The New - generation of FTA, Impact, Vietnam, Finance, Banking

\section{Introduction}

After Renovation in 1986, Vietnam has achieved many positive outcomes and progress in international integration. Vietnam is an active member of many international organizations such as ASEAN, APEC, WTO, etc. WTO is a global economic organization but now it is stuck in various problems related to multilateral relations. Therefore, in recent years, many countries around the World have intensified the signing of multilateral and bilateral Free Trade Agreements (FTAs) to create free trade areas. Not outside this trend, Vietnam has been negotiating and signing a lot of FTAs with others countries. Currently, Vietnam has been actively participating in negotiating and signing a number of bilateral and multilateral free trade agreements in the regional and international scope. Specifically, the following FTAs [5]:

1. ASEAN Free Trade Agreement CEPT / AFTA and ATIGA

2. ASEAN-China Free Trade Agreement (ACFTA)
3. ASEAN - South Korea Free Trade Agreement (AKFTA)

4. ASEAN-Japan Comprehensive Economic Partnership Agreement (AJCEP)

5. ASEAN-Australia-New Zealand Free Trade Agreement (AANZFTA)

6. ASEAN-India Free Trade Agreement (AIFTA)

7. Vietnam - Chile Free Trade Agreement

8. Vietnam - South Korea Free Trade Agreement

9. Vietnam - Japan Comprehensive Economic Partnership Agreement

10. Vietnam - EU Free Trade Agreement (EVFTA)

11.Comprehensive Trans-Pacific Partnership Agreement (CPTPP)

Notable are the new generation FTAs in recent years with European countries (EVFTA) or countries in the Pacific area (CPTPP). These new-generation of FTAs have significant impacts on all socio-economic activities in Vietnam, especially in the field of finance and banking. As a rapidly 
developing and fast growing economy, Vietnam holds substantial potential for business of EU and many countries in the Asia Pacific. The Partnership and Cooperation Agreements between Vietnam and EU or Vietnam and others 10 countries in Asia Pacific offer a solid foundation to intensify relations between parties, Vietnam enjoys trade preferences with EU and other countries in Asia Pacific towards further intensifying bilateral and multilateral relations. These FTAs cover issues of tariffs as well as nontariff barriers to trade. Moreover, they have regulations to govern issues related to others aspects of trade such as public procurement, regulatory issue, competition, services, investment, intellectual property rights, labour and sustainable development, etc.

Even though the integration into international trading system increased trade with the rest of the world, the effects of liberalization on welfare of Vietnam remain a critical issue among Vietnamese policy makers. A Free Trade Agreement between Vietnam and EU or Vietnam and others countries of Asia Pacific is expected to bring not only many new opportunities but also pose challenges for Vietnam's economy.

In this context, the paper aims to analyse the impacts of the new generation FTAs on Vietnam financial and banking activities. The first part of the paper, the author will analyse the trade between Vietnam and EU as well as other countries in Asia Pacific. The next part, the paper will mention the theoretical framework of trade creation and trade diversion effects of FTAs, Vietnam's specific commitments in the field of banking and financial services in some new generation FTAs and current situation of financial - banking enterprises in Vietnam. After that, I will give some assessment of FTA's impacts, analyses challenges to Vietnam's financial and banking industry when implementing new generation FTAs. At last, the author will end the paper with a conclusion and propose some solutions to make using of the new generation FTAs' advantages for Vietnam's Finance - Banking field better.

\section{Literature Review}

Free Trade Agreements (FTAs) are negotiated in order to gain access to new markets, remove or liberalize tariff, and non- tariff barriers, with the ultimate aim of enhancing the trade flows among the member countries. As a consequence of lack of progress in WTO negotiations, many countries opted for bilateral, regional and multi-lateral FTAs as an alternative to a comprehensive trade agreement at global level. Following the statistic of WTO, the number of Regional Trade Agreements (RTAs) increased from 79 in the year 2000 to 305 by 2020 . In line with the global trend, the countries in the Asia-Pacific region negotiated several RTAs to take advantage of the benefits associated with free trade. Vietnam is a signatory to 14 RTAs [16]. FTAs are considered to be the second-best option compared to the cumbersome WTO agreements. Some scholar argued that during the 90s, there has been a shift in East Asia from a focus on multilateral trade liberalization through the WTO to a pragmatic approach favoring bilateral and regional FTAs while continuing to support the WTO system. Every FTA aims to achieve certain specific objectives that are beneficial to the member countries such as free access to export markets. Wilson identified three motives as the drivers of FTAs in the Asia-Pacific region viz., trade liberalization, preferential access to key export markets, and/or the use of FTAs for political gains [19]. For example, the main objectives of Japan - Vietnam FTA include, encourage expansion and diversification of trade, and eliminate barriers to trade in, and facilitate the cross-border movement of, goods and services between the two countries. FTAs not only promote trade in manufactured goods but also increase the trade flows in agricultural products. A study of the impact of free trade agreements on agricultural trade flows in general and dairy, vegetable, live animals, meat and sugar in particular, among selected North African countries (Algeria, Egypt, Morocco and Tunisia) found that being a member of trade agreement is not only positively associated with aggregate agricultural trade flow but also potential for trade creation. The study estimated that trade agreement could increase agricultural trade flow by around 39 percent in trade volume is quite likely the benefits of an FTA may not be evenly enjoyed by the trading partners i.e. one member may gain more than the other member in a bilateral FTA due to certain inherent advantages. This should not imply that countries with implicit uneven distribution of resources should not negotiate FTAs as the benefits associated with FTAs exceed any disadvantages. As an example, ASEAN consists of developed countries such as Singapore, and developing countries such as Myanmar. The benefits arising out of economic integration and free-trade accrue to both these member economics albeit to different degrees. Given the positive influence of such economic and trade integration measures non-ASEAN members are negotiating an FTA with ASEAN to make it ASEAN+6. A study found that the expansion of ASEAN into ASEAN+3 and ASEAN+6 is important for promoting its members' exports through the elimination of tariff barriers, and forming an economic community with ASEAN. ASEAN+6 will help promote trade between these countries via the overall promotion of intraregional trade. In some study of ASEAN+6, FTA found that FTAs enhance the link between trade and FDI, promote Intra Industry Trade through horizontal and vertical integration, technological improvements, and product differentiation that facilitate regional value chains. Their empirical analysis concluded that a comprehensive FTA in goods among the ASEAN+6 countries under the Regional Comprehensive Economic Partnership results in enhanced trade flows among the member countries. Emiko Fukase and Will Martin also support the view that the FTA negotiations with non-ASEAN members such as India and forming a RCEP, will increase trade as well as FDI inflows benefiting the emerging economies [17]. In order to maximize the benefits of trade, apart from the FTAs, the role of proper infrastructure connecting the member countries is crucial. Physical connectivity in the form of transportation, communication, and modern banking facilities are essential 
to enjoy the benefits of free trade. Given the gains arising from FTAs, both bilateral and regional, there is scope for Vietnam to enhance merchandise exports to the selected member countries in the post CPTPP era [10]. The new generation of FTAs have started to form and develop in parallel with some other traditional FTAs. The main development motivation of the new generation FTA comes from the trend of globalization, the desire to expand the market, deeper integration into the international economies of the member countries and especially the rise of regionalism in the context of multilateral negotiations (within the framework of WTO) that comes to a standstill.

The trend of globalization along with regionalism has developed strongly in the 21 st century. The process of globalization facilitates and promotes trade activities and requires countries to conduct a thorough review of their country's socio-economic and cultural policies, along with raising high standards and conditions, working environment. The deeper trade liberalization, the more cooperation and production linkage are also promoted. At that time, production in the world, forming production networks was also strengthened. In addition, production around the world formed global production networks and value chains that each country, depending on its conditions and capabilities, became a link to participating in the chain segments that global value. On the other hand, the World trade activities are increasingly developing in line with the development of production and consumption activities. In the past, when trade activities were primarily associated with the production of tangible goods, many intangible products and services today appear to be the main objects of international trade. Entities who are traders in the world trade market also increase in number and size, conduct trade in many different industries and increasingly professionalize their activities. More modern transaction methods with the introduction of new types of commercial services. In addition, the activities of promoting investment, cooperation in technology transfer, facilitation of customs procedures in cooperation relations among countries, manufacturers and distributors have also been promoted.

In such a favorable condition, countries have negotiated free trade agreements with extremely rich and expanded content than previous FTAs. This is reflected in the fact that these new FTAs not only stop at commitments on promoting the liberalization of trade in goods and services, investment promotion but also new content. The scope of FTA commitments covers areas such as trade facilitation, investment, government procurement, competition policy, non-tariff measures, services, and intellectual property, innovative dispute resolution mechanisms, labor and environmental regulations, even democracy, human rights issues, etc. These new generation FTAs are increasingly developing strong in terms of both quantity and quality not only within the regional trade range but also throughout the globe.

\section{Research Methodology}

To finish the research in this paper, the author used many kinds of methodology such as using materials method via legal document - FTAs of Vietnam. Besides, survey and questionnaire also used for the study. Moreover, various modelling approaches and levels of aggregation have been used for analysing industrial location such as ordinary least squares. These procedures have been applied to foreign direct investment aggregated to the country level or the provincial level and, more frequently in recent years, to the firm level. By virtue of possessing a large and detail dataset, this study can use the conditional logic model to examine some hypothesis at the firm level.

\section{Results and Discussions}

\subsection{Vietnam's Specific Commitments in the Field of Banking and Financial Services in Some New Generation FTAs}

In EVFTA, Vietnam maintains the level of openness commitments to financial and banking services as in the agreements signed under the framework of the WTO in 2006. In principle, Vietnam is required to open markets minimum service market as committed in FTAs. However, Vietnam has the right to unilaterally open the market wider and higher than what has been committed in international treaties. Therefore, the market opening level is not always the actual market opening level. The actual market opening is mainly expressed through the provisions on investment and business conditions that apply specifically to foreign investors in Vietnam's domestic legal documents. For the financial and banking services that Vietnam has committed to the WTO, Vietnam's actual openness level is just equal to the committed level. In EVFTA, regarding services provided across borders, Vietnam only allows EU businesses to provide the following cross-border services to Vietnamese customers through the following methods [1]:

1. Supplying, transferring financial information and processing financial data

2. Consulting services, intermediaries and other auxiliary financial services

Regarding the establishment of a commercial presence of EU businesses in Vietnam, Vietnam pledged as follows:

- Regarding the type

+ Foreign banks are allowed to open commercial presence in any form; if it is a foreign-invested joint venture, it must not exceed $50 \%$; if it is a branch, it is not allowed to open a new establishment outside the branch's head office

+ Foreign finance / finance leasing company: is opened in any form except branches

- Once established, these applications are not restricted to receiving VND deposits

- In case EU businesses want to buy shares, types of Vietnamese enterprises: Vietnam still retains regulations on the amount of shares allowed to buy in state banks; for commercial banks, the maximum stake is $30 \%$.

In addition to EVFTA, CPTPP is also a new generation FTA with many impacts on Vietnam's financial and banking industry in the current period and in the near future. 
Commitments on financial services in the CPTPP require that member countries' traders provide many opportunities for access to markets and cross-border investment, while ensuring that member states of the CPTPP have capable of operating markets and financial institutions as well as taking emergency measures in case of financial crisis. Since the CPTPP is a multilateral trade agreement, the FTA also provides for the application of national treatment principles; most favoured nation treatment; access to markets when traders of member states provide financial services across borders. However, the CPTPP stipulates that, in the area of financial services, a service provider of one Member State may provide financial services in the market of another Member, if the Domestic companies operating in this market are allowed to provide such services [2].

Member States of the CPTPP must promulgate an exception to some of the rules in the two appendices attached to the CPTPP and in accordance with the conditions of each country. The CPTPP requires member states to be obliged not to impose any further sanctions in the future, as well as to comply with the liberalization agreement in future activities. The CPTPP also stipulates measures and policies of member states that have full autonomy in the future [6].

In the field of insurance services business, CPTPP member states have established principles for officially recognizing legal procedures to encourage the provision of insurance services by suppliers. Licensees and processes to achieve this goal. In addition, the CPTPP Agreement deals with specific commitments on portfolio management, electronic payment card services and information transfer for data processing purposes $[2]$.

However, the CPTPP also addresses exceptions in protecting the autonomy of financial managers of member states, in which they will be entitled to take proactive measures to strengthen their financial stability and consistency of its financial system; including the exceptions that member states carefully consider and the exceptions for non-discrimination measures in the process of establishing and implementing monetary policies or other policies [8].

\subsection{Current Situation of Financial - Banking Enterprises in Vietnam}

In the period 2005-2015, Vietnam's financial and banking sector achieved an average growth rate of about $7.5 \%$ per year, higher than the average GDP growth rate of the whole service industry in the same period. In 2018, the asset size of this field increased by $11.5 \%$ compared to 2017 , with total assets equivalent to $203 \%$ of GDP [14]. By 31 December 2018, Vietnam had a total of 388 enterprises and business organizations licensed to operate in 03 financial fields, specifically as follows.

These financial and banking businesses have created jobs for about 314,000 employees. This figure proves that the financial banking sector plays an extremely important role for the socioeconomic development of Vietnam in the current period.
Table 1. Enterprises and business organizations in financial fields, specifically.

\begin{tabular}{lll}
\hline Subdivision & Number of businesses & Total \\
\hline Insurance & 64 & 64 \\
Banks - Non-bank credit institutions & & 126 \\
The State Bank holds more than 50\% of & 04 & \\
charter capital & & \\
Domestic joint-stock commercial banks & 31 & \\
$100 \%$ foreign owned commercial banks & 09 & \\
Joint venture bank & 02 & \\
Cooperative bank & 01 & \\
Financial companies & 16 & \\
Financial leasing company & 10 & \\
Microfinance company & 04 & \\
Foreign bank branches & 49 & \\
Representative office of bank & 52 & \\
Securities & & \\
Securities companies & 105 & \\
Fund management company & 48 & \\
Custody bank & 14 & \\
Securities investment fund & 31 & \\
Foreign representative offices & 25 & \\
\hline
\end{tabular}

Enterprises operating in the Vietnam's field of finance and banking have made great progress and developments in professional skills, management skills, information technology and competitiveness in recent years. In a comprehensive view, many financial enterprises have experienced strong growth in terms of capital size, revenue and profit. However, due to complicated and unstable world economic situation, import-export and investment activities decelerated in 2018. In addition, due to the impact of trade wars of economies. Due to the large economic situation such as the US-China tension, the growth rate of the financialbanking sector has been slow compared to previous years. According to current statistics, the assets size of financial businesses reached 203\% of the country's GDP in 2018. Securities businesses have the fastest growth in size with an increase of over $20 \%$. Among the banking - finance sector, the group of credit enterprises accounts for the highest proportion, reaching $95.5 \%$ of the assets size of enterprises providing financial services. The total value of loans to the economy of credit enterprises is equivalent to $134 \%$ of GDP. The total assets of these businesses increased by $11.5 \%$, equity increased by $12.3 \%$, the bad debt ratio handled increased by $30 \%$ compared to 2017. The average profit after tax of these businesses increased by $40 \%$ in 2018 , this ratio in 2017 was $52.3 \%$. Securities businesses with total assets in 2018 increased by $20.3 \%$ of equity, up $22.8 \%$ compared to 2017 . In 2018 , the average profit after tax of these businesses increased by $15.3 \%$, while the rate of this is $70 \%$ in 2017 . In 2018 , the group of insurance businesses had an increase in total assets of $19.4 \%$, lower than in 2017 , this index was $25.8 \%$ [11].

\subsection{Positive Impact of FTAs on Financial - Banking Enterprises in Vietnam}

In EVFTA, Vietnam maintains the same level of open door commitments to financial and banking services as previously under WTO commitments. Specifically, for services provided across borders, businesses of the European Union (EU) are 
allowed to provide cross-border services to customers in Vietnam, including provision, transfer of information and financial data processing, consulting services, intermediaries and other ancillary financial services. The countries in the European Union (EU) are one of the two largest export markets of Vietnam today. The EU is also Vietnam's third largest trading partner globally. European countries have also been a major investor in Vietnam for many years. In 2017, there are 24 out of 28 EU countries have invested in Vietnam with about 2,000 valid projects, with a total registered capital of over US \$21.5 billion [5]. EU investors have invested in the most important economic sectors of Vietnam, focusing on industry, construction and a number of service sectors, including financial - banking services. Therefore, the successful negotiation of Vietnam and EU free trade agreements (EVFTA) is a very necessary work and it is considered to have a positive impact on the economies of the parties, including activities in the field of finance - banking. The agreement will help European companies prioritize access to the market of nearly 100 million Vietnamese consumers, increase investment, create more jobs and boost trade with one of Asia's most dynamic economies. Vietnamese exporters will also have the opportunity to reach potential customers who are citizens of European Union member countries with high income and great consumer demand. Products and services in the structure of import and export between Vietnam and the EU do not directly compete with each other but on the contrary, complementary and supporting each other. It is the different natural and social conditions that lead to different products and goods of Vietnam and the EU. This is a condition for Vietnam and the EU to enhance the export and import of each other's goods. In 2016, the two-way trade turnover has increased more than 10 times, from 4.1 billion USD in 2000 to over 50.4 billion USD; in which Vietnam's exports to the EU increased by 13.6 times and imports from the EU to Vietnam increased by more than 9 times. The main groups of Vietnam's exports to the EU today are footwear, textiles, coffee, furniture and seafood. Once EVFTA takes effect, Vietnam commits to immediately eliminate $65 \%$ of import taxes from the EU, and the rest will be eliminated according to the schedule within 10 years. EVFTA when implemented, especially the removal of tariffs, investment promotion, promotion of mutual recognition of standards, improvement of rules of origin and certification of origin; improve the trade facilitation environment between Vietnam and EU countries to develop comprehensively and quickly. EU countries also provide technical assistance to raise awareness and apply EU market standards. These activities will bring many opportunities for Vietnam to expand exports, attract investment and participate more deeply in the global value chain [7]. This will facilitate the development of trade activities, leading to the use of financial - banking services in payment, goods insurance will develop. The implementation of e-commerce also helps the use of electronic payment methods such as electronic wallets and e-banking to develop strongly.

In the past 10 years, Vietnam's financial market has grown at a high and stable level. Financial - banking services of Vietnam are very potential based on the development of investment activities, production, business, and import and export businesses. In addition, the income and consumption level of the population increased rapidly along with changes in monetary management policies; Financial - banking enterprises have made significant changes in professional skills, management skills, information technology, thereby gradually improving their competitiveness as the necessary factors to promote the development of a financial market major is growing. Therefore, when the commitments in EVFTA and CPTPP are officially put into effect, the demand for financial services will increase with the growth of production, business and import-export activities to take advantage of tariff treatment in this new generation FTA. The new generation FTAs also provide opportunities for investors to do business in financial services of Vietnam in foreign markets because partner countries will open financial services to Vietnam at the highest level. In fact, right after EVFTA was signed, many potential EU financial investors came to survey and explore Vietnam's financial market. Along with that is the organization of bilateral, multilateral forums and conferences among partners to find out investment opportunities. It shows that investors from EU countries are more interested in Vietnam's financial market and EVFTA motivates them to invest more [3].

\subsection{Challenges to Vietnam's Sector of Financial and Banking When Implementing New Generation FTAs}

In addition to the positive effects, the FTA also pose significant challenges for the banking and finance sector of Vietnam.

Firstly, the competitive pressure from foreign financial service providers in Vietnam market is increasing. This pressure on the one hand is due to Vietnam's opening, the financial services market under some FTA commitments (for example in AFTA/ATIGA, in CPTPP), thereby paving the way for many foreign financial service providers to invest in Vietnam or provide cross-border services that compete with Vietnamese enterprises [12]. On the other hand, Vietnam has strongly opened its economy under FTAs, making trade - investment and import-export activities very exciting. Since then, creating an attractive market to attract the participation of foreign financial service providers in Vietnam, leading to strong pressure to compete with Vietnam's financial enterprises.

The demand for financial services in Vietnam is increasing day by day. It does not only stop at the price of the service but also requires a high quality of service. Along with the integration process, the development of technology and the ability to innovate and meet the needs of clients. The clients using financial services in Vietnam also have increasingly higher requirements for quality, type and price of financial services. In the context that Vietnam has opened its doors, gradually removed restrictions on foreign financial service providers, Vietnamese financial enterprises have been forced to compete more equally to attract clients.

The application of science and technology in financial services poses challenges in management and information security (cyber-security). The challenge of safety transaction and 
information security in financial transactions, especially electronic transactions. For all financial service providers applying technology, this challenge even bigger. For Vietnamese enterprises at the lower technological level, the investment resources for this field are not yet able to compete with foreign enterprises. Thus, this is really a big problem for the financial banking sector of Vietnam in the current and future stages.

These challenges are not new to Vietnam's financial and banking enterprises when signing and implementing new generation FTAs. They have existed for a long time and still challenge the Vietnam's economic until now. In recent years, many Vietnamese financial and banking enterprises have been finding solutions to overcome these obstacles to improve their competitiveness.

\section{Conclusion and Recommendation}

\subsection{Conclusion}

From the above analysis and evaluation, we can see that the signing of new generation free trade agreements of Vietnam is extremely necessary in the current period. These FTAs have had great impacts on the overall socio-economic life of Vietnam in general and on the financial and banking sector in particular. The implementation of commitments in these FTAs not only brings positive benefits such as promoting fast-growing financial and banking activities with many new products and services, operating models more and more expanding not only the domestic market and global scale, but also they have a positive impact on the reform of institutions and laws of the finance - banking field, consumption habits of financial - banking services. Vietnamese clients' products of services will also change. When opening the market in the field of finance and banking, an urgent issue is raised the competitiveness of domestic banks to be able to compete with foreign banks from other countries. The country is a signatory to the new generation FTAs. At the same time, the weak financial institutions will be bankrupt. They will be eliminated from the market, only retaining really good and reputable financial and banking institutions in the economy. Therefore, it will create a more sustainable development of finance and banking sector so that there will be better financial providers to meet the needs of clients. In addition to the positive benefits, the new generation FTAs bring to the financial and banking industry of the signatories, these FTAs also pose significant challenges for state management agencies as well as enterprises operating in the Vietnam's field of finance banking in the near future. Therefore, a comprehensive and completely assessment, identifying the positive effects, opportunities and challenges that new generation FTAs bring is a very necessary work for both Government authorities and business organizations in the field of finance and banking so that they can build action plans and appropriate solutions for each specific situation, bringing real efficiency exam the highest of these FTAs.

\subsection{Recommendation}

From the above analysis, in order to promote the positive effects and make the most effective use of advantages as well as overcome the negative aspects and challenges that the new generation FTA poses to state management agencies and enterprises operating in Vietnam's financial sector need to find feasible solutions.

In order to adapt and improve the effectiveness of implementation of commitments in EVFTA and CPTPP, competent state agencies need to develop a specific national roadmap and action plan with specific action plans from central to local. Accordingly, the authorities need to pay attention to reviewing the specific commitments of the financial - banking sector in the new generation FTAs. From there, establish a list of institutional issues that need to be addressed (including laws and management and operation apparatus). Especially, measures to support capacity building, technical contributions, mechanism design and support resources to build and operate the apparatus in accordance with the nature, functions and ensure feasibility in development declaration; strengthening the quality of market institutions' management of institutions providing banking and financial services [9].

Banks and financial institutions also need to proactively identify and prepare capacity, specific plans on information, finance, human resources and technology... to exploit opportunities and overcome challenges. On the basis of practicality and commitment roadmaps are publicly provided by the authorities. Vietnam's financial and banking institutions need to innovate their development models, improve their quality, and create new types of services to meet customer needs as well as be able to compete with services of the foreign banks in Vietnam after the new generation FTAs take effect.

To make the most of the benefits and overcome the challenges that the new generation FTAs bring, first of all Vietnamese banks and financial companies need to have a workforce of staffs. High quality meets the increasing requirements in the process of international integration. This is a necessary condition for the bank to improve the quality of its products and services, thereby creating a better competitiveness to compete with foreign banks when Vietnam opens its financial and banking market for foreign investors after the FTAs come into effect. In addition to recruiting employees who have knowledge, skills, and high professional qualifications in banking and finance, banks and financial companies also need training, retraining and test existing labourers so that they can accumulate new experiences and new knowledge to meet the increasing requirements in the period of integration and the $4^{\text {th }}$ industrial revolution. At the same time, they will also eliminate weak, slow-working, low-skilled staffs to replace them with high-skilled ones. Banks and financial companies also need appropriate remuneration policies to keep talented people working for themselves, to avoid brain drain. Further, they need to have solution to avoid the shift of high-quality human resources from Vietnam to regional 
countries and the world.

International economic integration has made an important contribution to the expansion of the market of financial and banking services in Vietnam. Besides the opportunities, the new generation FTAs can also pose many risks and challenges for the economy in general and the finance - banking industry in particular. Therefore, the financial - banking system needs to constantly innovate, create and improve governance. The governance capacity of Vietnamese banks and financial institutions has significantly improved over the years, but has not yet met practical needs, under an increasing competition pressure in international integration trend today. Thus, besides receiving capital from foreign investors, Vietnamese banks and financial companies need to gather experience and learn management skills from foreigners through the transfer technology process and training from foreign experts, managers who are foreigners in organizations in Vietnam. During the first time of running the organization, it is possible to hire foreign managers and executives with professional knowledge and skills. In the meantime, Vietnam's managers and executives in banks and financial institutions also need to quickly acquire new management knowledge and skills in order to run banks and financial institutions. Vietnam is able to effectively compete with foreign banks operating in Vietnam as well as expand the market of Vietnamese banks abroad when FTAs come into effect. By doing so, Vietnamese financial institutions and banks can overcome challenges to make the most of the benefits that the new generation FTAs bring [18].

The issue of technology and security also poses many challenges to the current banking and finance industry, especially the increase in cybercrime with foreign transactions. To protect the clients, not only the banks and financial companies strengthen cyber security but also the Government and related authority agencies need to support them, co-operate with them to prevent and fight the crimes.

\section{Limitation and Study Forward}

This study does not cover all aspects of the FTAs' impacts on financing and banking sector in Vietnam. Author just mentions impact of two main new generation FTA of Vietnam with partners. They are EVFTA and CPTPP. In this paper, the author uses some statistic of Vietnam Government and some specialist to assess and analysis the roles and impacts of these FTA on the activities of financial and bank enterprises in Vietnam. From there, the author withdraws some lesson and recommendation solution to use FTA more effectively to develop banking and financing sector of Vietnam in next period. In the future, the author has plan to make other study about new generation FTAs' impacts on other Vietnam economic sectors such as tourism, industry, agriculture, manufacture, importation and exportation, etc [4].

\section{References}

[1] European Union - Vietnam Free Trade Agreement (EVFTA).

[2] Comprehensive and Progressive Agreement for Trans-Pacific Partnership (CPTPP).

[3] Yen Vu, Tue Do, Vu Ngoc Duong (2020). What you need to know to implement the EU-Vietnam Free Trade Agreement (EVFTA). From:

https://www.researchgate.net/publication/344013932_What_y ou_need_to_know_to_implement_the_EU-

Vietnam_Free_Trade_Agreement_EVFTA.

[4] Chien-Huei Wu (2020). ASEAN at the Crossroads: Trap and Track between CPTPP and RCEP. Journal of International Economic Law 23 (1): 97-117. DOI: 10.1093/jiel/jgz032.

[5] http://rtais.wto.org/UI/PublicMaintainRTAHome.aspx.

[6] Nguyen Hoang Tien (2020). Challenges of CPTPP without USA for Vietnam. Conference: Proceedings of University Scientific Conference: "Impact of Concluded FTA on Young Labor Forces and Vietnam's Economy". Banking University in Ho Chi Minh City, Centre for Young Science and Technology Development. 03 December 2019, Ho Chi Minh City. At: Ho Chi Minh City, Vietnam.

[7] Nadezhda Volovik (2016). Free Trade Zone between Eurasian Economic Union and Socialist Republic of Vietnam Comes into Force. SSRN Electronic Journal. DOI: $10.2139 / \mathrm{ssrn} .2856456$

[8] Jun Ha Kang (2019). CPTPP and Inclusive Growth. Korean Journal of International Economic Law 17 (3): 7-29. DOI: 10.46271/KJIEL.2019.11.17.3.7.

[9] Nguyen Van Nen (2020). Factors affecting Vietnam's wooden furniture export into CPTPP countries. Science \& Technology Development Journal - Economics - Law and Management 4 (2). DOI: $10.32508 /$ stdjelm.v4i2.617.

[10] Collins Ajibo, Samuel I Nwatu, Festus Okechukwu Ukwueze, Newman Richards (2019). RCEP, CPTPP and the Changing Dynamics in International Trade Standard-Setting, Manchester Journal of International Economic Law 16 (3): 425-440.

[11] Ngo Thi Tuyet Mai, Ngo Thanh Xuan (2019). Opportunity to receive Japan's direct investment in Vietnam when performing CPTPP. Conference: International Federation of East Asian Management Associations At: Kyoto, Japan.

[12] Heng Wang (2019). The Future of Deep Free Trade Agreements: The Convergence of TPP (and CPTPP) and CETA? Journal of World Trade 53 (2).

[13] Satya Gonuguntla (2019). Potential Gains to New Zealand From CPTPP Membership. Asian Business Research 4 (2): 14 DOI: $10.20849 /$ abr.v4i2.617.

[14] Vietnam Chamber of Commerce and Industry (2018), Guidance manual for implementation of EVFTA and CPTPP of Vietnam Chamber of Commerce and Industry (VCCI).

[15] Aitken, N. D. (1973): "The effect of the EEC and EFTA on European trade: A temporal cross-section analysis", American Economic Review, 63, 881-892. 
[16] Claudio Dordi, Federico Lupo Pasini (2011): "The impact of Vietnam - EU FTA on some selected importing sector of Vietnam", WTO center.

[17] Emiko Fukase and Will Martin (1999): “A Quantitative Evaluation of Vietnam's Accession to the ASEAN Free Trade Area (AFTA)", World Bank report.

[18] Thu Ha Le (2017), Trade Impacts of the European Union
Vietnam Free Trade Agreement: The Sussex Framework Analysis, SSRN Electronic Journal, DOI: $10.2139 /$ ssrn. 2932079 .

[19] Carsten Weerth (2020), EU-Vietnam Free Trade Agreement (EVFTA) in: Gabler Wirtschaftslexikon Online, In book: Gabler Wirtschaftslexikon Online Publisher: Springer Gabler Verlag, Project: Free Trade Agreements and Customs Unions of the World. 